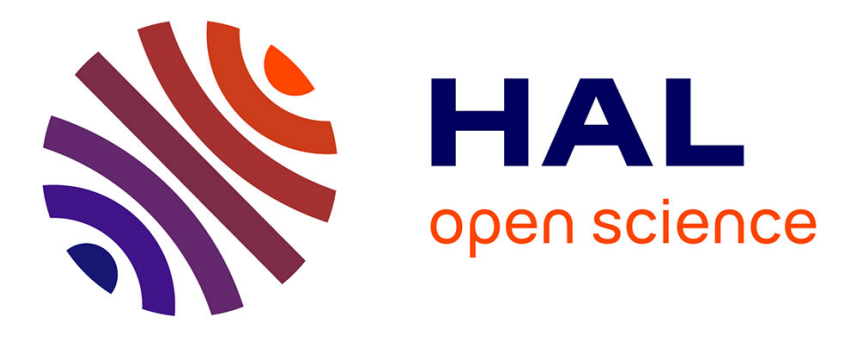

\title{
High sensitive mesoporous TiO2-coated Love wave device for heavy metal detection
}

\author{
Ibtissem Gammoudi, Laurianne Blanc, Fabien Moroté, Christine \\ Grauby-Heywang, Cédric Boissière, Rafik Kalfat, Dominique Rebière, Touria \\ Cohen-Bouhacina, Corinne Dejous
}

\section{To cite this version:}

Ibtissem Gammoudi, Laurianne Blanc, Fabien Moroté, Christine Grauby-Heywang, Cédric Boissière, et al.. High sensitive mesoporous TiO2-coated Love wave device for heavy metal detection. Biosensors and Bioelectronics, 2014, 57, pp.162-170. 10.1016/j.bios.2013.12.024 . hal-00914710

\author{
HAL Id: hal-00914710 \\ https://hal.science/hal-00914710
}

Submitted on 25 Feb 2015

HAL is a multi-disciplinary open access archive for the deposit and dissemination of scientific research documents, whether they are published or not. The documents may come from teaching and research institutions in France or abroad, or from public or private research centers.
L'archive ouverte pluridisciplinaire HAL, est destinée au dépôt et à la diffusion de documents scientifiques de niveau recherche, publiés ou non, émanant des établissements d'enseignement et de recherche français ou étrangers, des laboratoires publics ou privés.

\section{(ㅇ)(1) $\$$}

Distributed under a Creative Commons Attribution - NonCommerciall 4.0 International 


\title{
High sensitive mesoporous $\mathrm{TiO}_{2}$-coated love wave device for heavy metal detection
}

\author{
I. Gammoudi a,b,c,*, L. Blanc ${ }^{\mathrm{a}}$, F. Moroté ${ }^{\mathrm{b}}$, C. Grauby-Heywang ${ }^{\mathrm{b}}$, C. Boissière ${ }^{\mathrm{d}}$, R. Kalfat ${ }^{\mathrm{c}}$, \\ D. Rebière ${ }^{\mathrm{a}}$, T. Cohen-Bouhacina ${ }^{\mathrm{b}}$, C. Dejous ${ }^{\mathrm{a}}$ \\ a Univ. Bordeaux, IMS, CNRS UMR 5218, IPB, Univ. Bordeaux 1, Talence, France \\ b Univ. Bordeaux, LOMA, CNRS UMR 5798, 351 crs Libération, 33405 Talence, France \\ c National Institute for Research and Physicochemical Analysis, BiotechPole, Sidi Thabet, Tunisia \\ ${ }^{\mathrm{d}}$ LCMCP, Collège de France - CNRS-UMR 7574, Paris, France
}

Keywords:

$\mathrm{TiO}_{2}$ mesoporous

Biosensor

Heavy metals

Escherichia coli

Polyelectrolyte

Love-waves

AFM

\begin{abstract}
A B S T R A C T
This work deals with the design of a highly sensitive whole cell-based biosensor for heavy metal detection in liquid medium. The biosensor is constituted of a Love wave sensor coated with a polyelectrolyte multilayer (PEM). Escherichia coli bacteria are used as bioreceptors as their viscoelastic properties are influenced by toxic heavy metals. The acoustic sensor is constituted of a quartz substrate with interdigitated transducers and a $\mathrm{SiO}_{2}$ guiding layer. However, $\mathrm{SiO}_{2}$ shows some degradation when used in a saline medium. Mesoporous $\mathrm{TiO}_{2}$ presents good mechanical and chemical stability and offers a high active surface area. Then, the addition of a thin titania layer dip-coated onto the acoustic path of the sensor is proposed to overcome the silica degradation and to improve the mass effect sensitivity of the acoustic device.

PEM and bacteria deposition, and heavy metal influence, are real time monitored through the resonance frequency variations of the acoustic device. The first polyelectrolyte layer is inserted through the titania mesoporosity, favouring rigid link of the PEM on the sensor and improving the device sensitivity. Also, the mesoporosity of surface increases the specific surface area which can be occupied and favors the formation of homogeneous PEM. It was found a frequency shift near $-20+1 \mathrm{kHz}$ for bacteria immobilization with titania film instead of $-7 \pm 3 \mathrm{kHz}$ with bare silica surface. The sensitivity is highlighted towards cadmium detection.

Moreover, in this paper, particular attention is given to the immobilization of bacteria and to biosensor lifetime. Atomic Force Microscopy characterizations of the biosurface have been done for several weeks. They showed significant morphological differences depending on the bacterial life time. We noticed that the lifetime of the biosensor is longer in the case of using a mesoporous $\mathrm{TiO}_{2}$ layer.
\end{abstract}

\section{Contents}

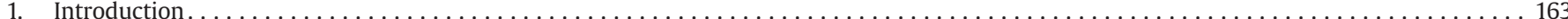

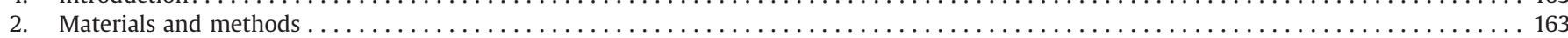

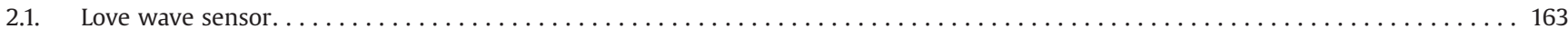

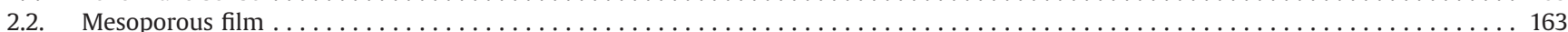

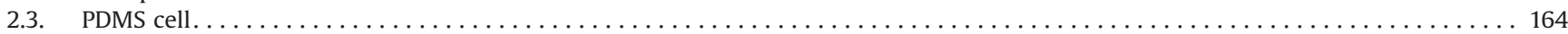

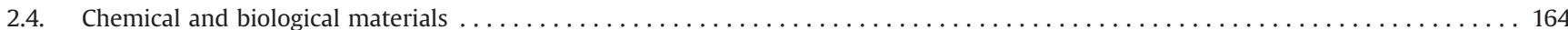

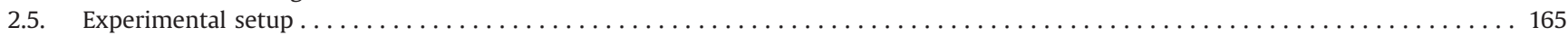

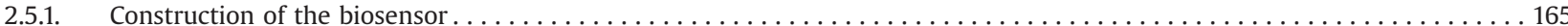

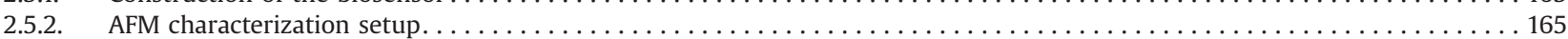

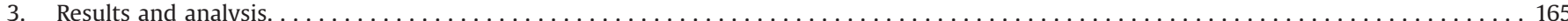

3.1. Acoustic response for polyelectrolyte multilayer and bacteria deposition $\ldots \ldots \ldots \ldots$

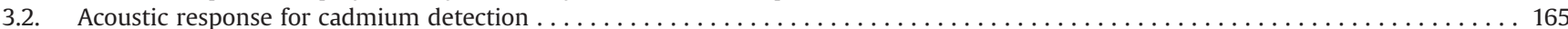

\footnotetext{
* Corresponding author.

E-mail address: ibtisem.gammoudi@u-bordeaux1.fr (I. Gammoudi).
} 


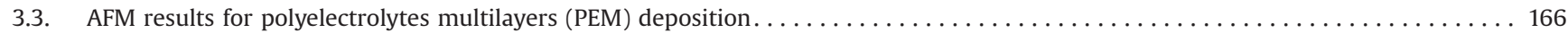

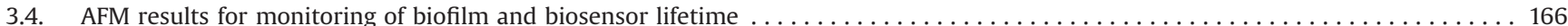

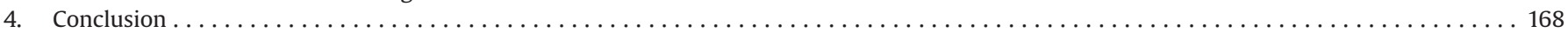

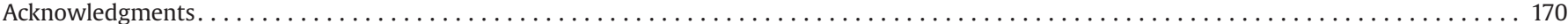

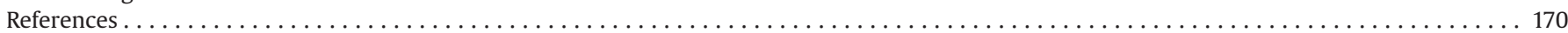

\section{Introduction}

Heavy metals pollution is a major health issue, representing a serious threat for worldwide citizens, especially in poor countries. Some studies now indicate that anthropogenic sources overcome natural emissions, as in the case of mercury (Seigneur et al., 2004). The toxicity is related to an excessive build-up of metals in the body. Heavy metal toxicity can result in damaged or reduced mental and central nervous function (Panphlett et al., 2001). Long-term exposure may result in slowly progressing physical and neurological degenerative processes that mimic Alzheimer's or Parkinson's disease (Matés et al., 2010).

To prevent the accumulation of these toxic chemical species in the tissues, or in the environment, there is a strong need for a portable, low cost, early detection method for in situ monitoring of heavy metal concentrations. Conventional methods have been used for the cadmium heavy metal analysis in water and food such as inductively coupled plasma mass spectrometry (ICPMS) (Valderi et al., 1998), atomic absorption (AA) (Bagher et al., 2012) spectroscopy or inductively coupled plasma (ICP) (Sereshti. et al., 2011). While these methods are usually efficient, the cost per sample is very high, the purification and sample processing steps can be very long, and they need sophisticated equipment and extreme control of experimental procedures. Other unconventional methods for heavy metals detection were developed and exist in literature. For example Hepel et al. investigated gold nanoparticle networks mediated by $\mathrm{Cd}^{2+}$ and $\mathrm{Pb}^{2+}$ ions using several methods such as laser-pulsed dynamic light scattering (DLS) and transmission electron microscopy (TEM) (Hepel et al., 2012). Ultra-sensitive thymine-thymine (T-T) mismatch-based oligonucleotide molecular beacon was also applied in analytical determinations of $\mathrm{Hg}^{2+}$ ions (Stobiecka et al., 2012).

The development of highly sensitive and selective biosensors for heavy metal ions in an aqueous solution is thus a challenging target of environment pollutant detection (Castillo et al., 2004).

A promising sensing system for the real-time detection of trace heavy metal ions in aqueous solution is the sensor based on Loves (Fertier et al., 2009). Acoustic device presents several advantages such as a high sensitivity, a real-time response and liquid media suitability. However, $\mathrm{SiO}_{2}$ layer, typically used as guiding layer for Love waves, suffers from some drawbacks, especially for biological applications (Sanchez et al., 2005). To overcome these drawbacks, we demonstrate the value of an additive coating overlayed on $\mathrm{SiO}_{2}$ surface.

Indeed, with recent advances in materials science and nanotechnologies, the development of mesoporous materials is a key to design highly sensitive and selective sensors (Tortissier et al., 2009). These enhanced properties are attributed to their high specific surface areas, large pore diameters and uniform pore size. Among all, mesoporous $\mathrm{TiO}_{2}$ presents some interesting properties such as non-toxicity, and biological and chemical stabilities. In addition, $\mathrm{TiO}_{2}$ is inexpensive and reusable. Then, mesoporous $\mathrm{TiO}_{2}$ was used as an intermediate layer to construct a film of polyelectrolytes (PE) for Escherichia coli bacteria immobilization on the sensor surface.

In this work, the aim is to use a mesoporous $\mathrm{TiO}_{2}$ layer to protect the $\mathrm{SiO}_{2}$ guiding layer from saline solution. Moreover, due to its mesoporosity, this thin film improves the sensitivity of the sensor and the E. coli based biosensor lifetime. The sensor sensitivity is measured through cadmium detections, whereas the biosensor lifetime is studied by AFM. This technique has been used under ambient conditions for imaging different cellular systems (Gauthier et al., 1996; Bouhacina et al., 2000).

In a first part, materials and methods involved in the acoustic sensor realization are presented. Then, the experimental setup is described. Finally, typical responses obtained with the acoustic sensor and AFM characterization are presented and analyzed.

\section{Materials and methods}

\subsection{Love wave sensor}

The Love wave sensor (Fig. 1) is constituted of a piezoelectric quartz substrate (AT cut). Interdigital transducers (IDTs) are deposited by lift-off photolithography in order to generate pure shear horizontal acoustic waves propagating perpendicular to the $X$ crystallographic axis. IDTs are composed of $44 \mathrm{Ti} / \mathrm{Au}$ split-finger pairs with a periodicity $(\lambda)$ of $40 \mu \mathrm{m}$. The acoustic path length, between both IDTs, is $164 \lambda$ and the IDTs aperture $(W)$ is $39 \lambda$. A $4 \mu \mathrm{m} \mathrm{SiO}{ }_{2}$ guiding layer, deposited on the substrate through PECVD, confines the acoustic wave energy near the surface to maximize the sensor sensitivity (Zimmermann et al., 2001), resulting in a so-called Love wave. In addition, it ensures the insulation of IDTs from the biological medium.

Once placed in the retroaction loop of a radio-frequency amplifier, the synchronous frequency of the device is close to $117 \mathrm{MHz}$. Any modification of mass or viscoelastic properties on the sensor surface can be electronically measured as a frequency shift. More details on the whole device can be found in Tortissier et al. (2009).

\subsection{Mesoporous film}

Among several advantages, mesoporous materials offer a high active specific surface area due to their controlled porosity and pore size distribution. They can be chosen among a large variety of mesoporous metal oxides $\left(\mathrm{TiO}_{2}, \mathrm{SiO}_{2}, \mathrm{ZnO}, \mathrm{WO}_{3}\right.$, etc. $)$ and they offer possibilities of functionalization (Nicole et al., 2005). Therefore, they are very relevant for chemical sensor applications (Tiemann, 2007), and previous work has shown great potentialities of Love wave platforms for VOC (volatile organic compound) detection using mesoporous $\mathrm{TiO}_{2}$ as a sensitive layer (Tortissier et al., 2009).

In this study, mesoporous titanium dioxide was used as a protective layer due to its good mechanical and chemical stabilities in biological media compared to $\mathrm{SiO}_{2}$ (Bass et al., 2007). Moreover, the insertion of polyelectrolyte into the mesoporosity form an organic/inorganic matrix, rigidly linked to the substrate, which enhanced the sensitivity of the acoustic platform (Wang et al., 2012).

The film was prepared via the sol-gel process, which enables the full control of the film structural properties (Fig. 1) (Sanchez et al., 2005; Nicole et al., 2005). The precursor solution contained $20.66 \mathrm{~g}$ of ethanol, $1.45 \mathrm{~g}$ of acid water $\left(\mathrm{pH}^{<} 7\right)$ and $0.56 \mathrm{~g}$ of Pluronic ${ }^{\mathbb{R}}$ F127 as surfactant and $3.347 \mathrm{~g}$ of a mixture of $\mathrm{TiCl}_{4}$ and EtOH with a molar ratio $\mathrm{TiCl}_{4} / \mathrm{EtOH}=1 / 5$. 
A
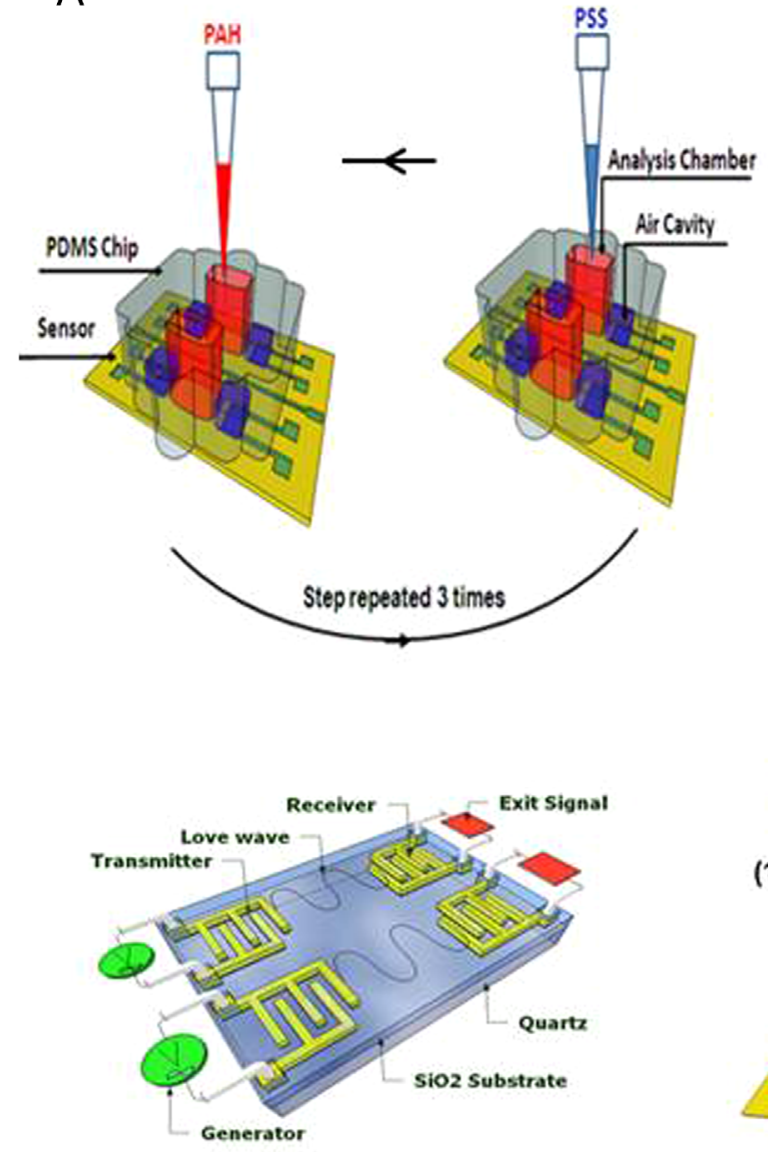

B
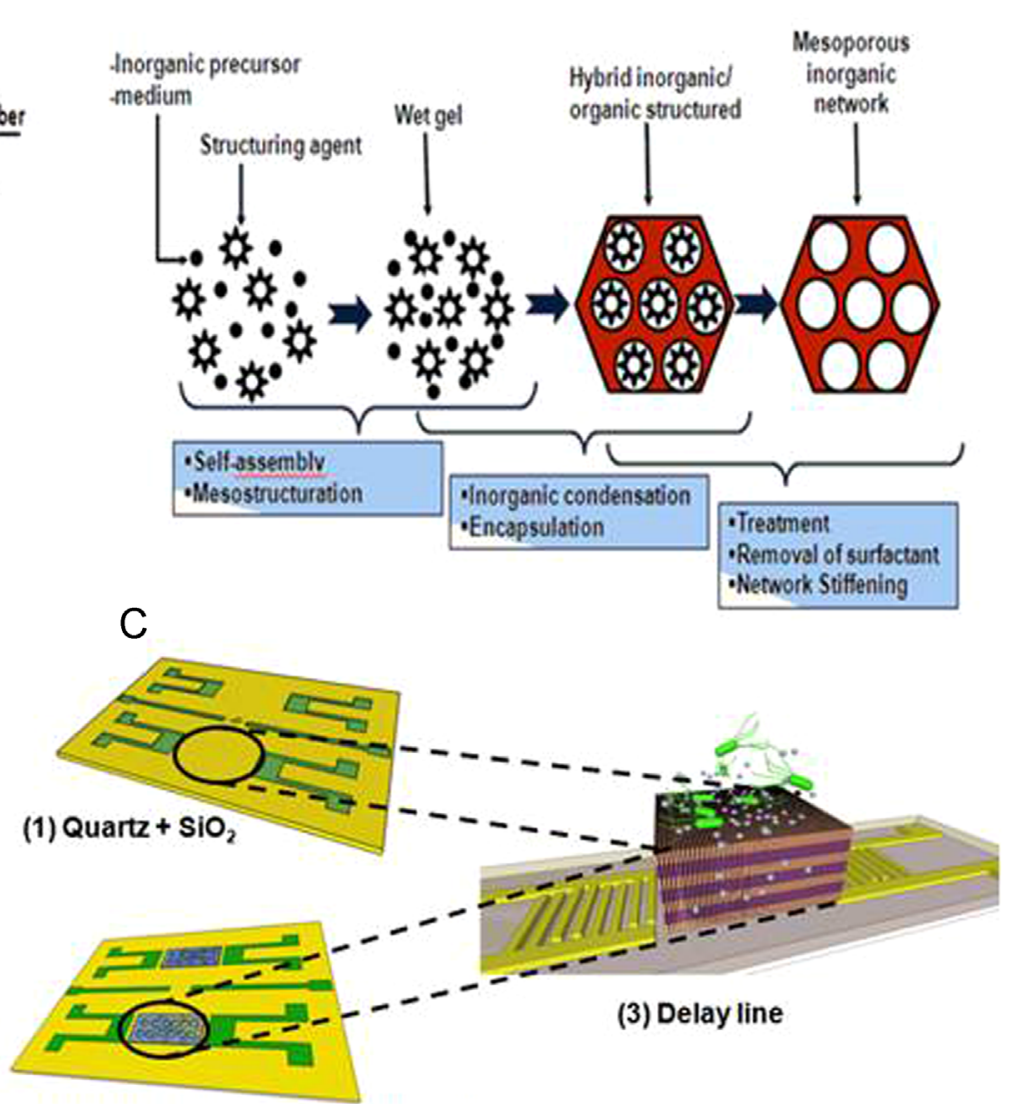

(2) Quartz $+\mathrm{SiO}_{2}+\mathrm{TiO}_{2}$ mesoporous

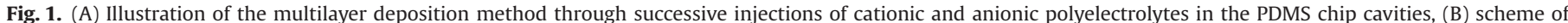

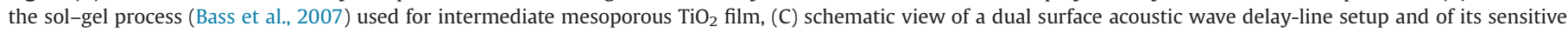

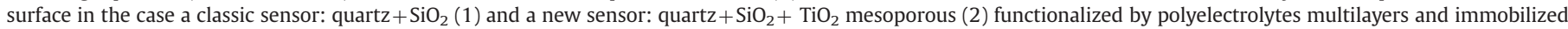
bacteria.

The solution was spread by spin-coating at $1000 \mathrm{rpm} / \mathrm{s}$ acceleration and 2000 rpm velocity, on the acoustic path of the sensor. Then, the device spent $10 \mathrm{~h}$ in a climatic chamber set at $75 \% \mathrm{RH}$ (relative humidity) at ambient temperature. A dedicated thermal cure was finally applied to obtain a homogeneous porous film: first, from ambient temperature to $400{ }^{\circ} \mathrm{C}$ with a $5{ }^{\circ} \mathrm{C} / \mathrm{min}$ ramp; then, five hours at $400{ }^{\circ} \mathrm{C}$; and finally, back to the ambient temperature at the same rate.

Eventually, the mesoporous layer has been characterized through ellipsometric porosimetry (Boissière et al., 2005), which showed a porosity of $21 \%$ with an average pore size of $6 \mathrm{~nm} \times 9 \mathrm{~nm}$. The film thickness was about $100 \mathrm{~nm}$.

\subsection{PDMS cell}

Poly (dimethylsiloxane) or PDMS cell was also previously designed and is described elsewhere (Gammoudi et al., 2010). Briefly, it was used to protect the IDTs for operation in liquid medium (Tarbague et al., 2010), in order to define a limited zone for fluid samples on the acoustic path as it can be seen in Fig. 1. Some advantages of PDMS for this application are its electrical insulation ability, controlled rubbery behavior, optical transparency, biocompatibility and low cost. It consists of a base and a curing agent (respectively 10:1 in weight), mixed and placed in a vacuum oven for degassing, then poured on a dedicated microfabricated mold and cured for $2 \mathrm{~h}$ at $65{ }^{\circ} \mathrm{C}$ to achieve reticulation. The cell is maintained by pressure on the delay lines (Fig. 1A), and liquids are injected in and removed from cavities using a micropipette.

\subsection{Chemical and biological materials}

The polyelectrolytes (PE) considered in this work are poly (allylamine hydrochlorure) (PAH), as a cationic polyelectrolyte (Mw $=56,000)$, and poly (styrene sulfonate) (PSS), as an anionic polyelectrolyte $(\mathrm{Mw}=70,000)$. PAH and PSS solutions $(5 \mathrm{mg} / \mathrm{ml}$ in 0.15 M TBS (Tris-Buffered Saline)) were alternatively deposited through the "layer-by-layer" (LbL) method on the $\mathrm{TiO}_{2}$ coated Love wave sensor. This method consists in sequential depositions of oppositely charged solutions to form a self-assembled molecular multilayer (Schonhoff and Opin 2003). All these products are purchased from Sigma Aldrich.

Bacteria E. coli was used as bioreceptors due to their high sensitivity to the presence of heavy metals such as cadmium and mercury but without selectivity of ions. In fact, heavy metals have an inhibitory activity of enzymes on microorganisms (Wood and Wang, 1983). Also, a presence of heavy metals ions can lead to cellular disfunctioning like DNA damage (Zhou et al., 2008), and cell membrane alteration (Guven et al., 2003). E. coli were grown in Petri dishes containing a solid medium nutritive agar. They were suspended in a volume of $0.15 \mathrm{M}$ of TBS calculated to obtain a final concentration of $10^{8}$ cells/ml.equivalent to D.O. (optical density at $600 \mathrm{~nm}$ ), that allowed good coverage of the biofilm on the sensor surface (results not shown) 
The cadmium solution was prepared from $\mathrm{Cd}\left(\mathrm{NO}_{3}\right)_{2} \cdot\left(\mathrm{H}_{2} \mathrm{O}\right)_{4}$ (from Sigma-Aldrich) in the same TBS buffer as a reference solution. Four selected concentrations, $10^{-12}, 10^{-9}, 10^{-6}$ and $10^{-3} \mathrm{M}$, were prepared from this reference solution with successive dilutions. Note that other heavy metals can be detected with this biosensor (Gammoudi et al. 2010), resulting in monitoring the overall toxicity of the test sample.

\subsection{Experimental setup}

\subsubsection{Construction of the biosensor}

Two devices were used, the first one is a "classic" Love wave sensor (quartz $+\mathrm{SiO}_{2}$ guiding layer) and the second one is a Love wave platform coated with an additional mesoporous $\mathrm{TiO}_{2}$ film.

The PE solutions were injected on the devices in the analysis chamber of the PDMS chip for 10-20 min. After an initial deposition of PAH (positively charged), a PSS layer (negatively charged) was deposited, which constitute the $\mathrm{PEM}_{1}$ (first polyelectrolyte multilayer). This operation was repeated three times in order to obtain three PAH-PSS bi-layers $\left(\mathrm{PEM}_{1}\right.$ to $\left.\mathrm{PEM}_{3}\right)$. After $\mathrm{PEM}_{3}$ layers, a fourth PAH layer allowed the adhesion of bacteria (negative charge). Finally, solutions with different cadmium concentrations were successively injected onto and withdrawn from the so-obtained E. coli-based biosensor.

\subsubsection{AFM characterization setup}

AFM experiments (Simon et al., 2004) were carried out with a Bioscope II mounted on an Olympus inverted optical microscope and operating with the NanoScope V controller (Veeco-Brucker, Santa Barbara, CA). This technique is based on the detection of small forces existing between a tip and an object (the surface sample) which is scanned along the tip with a piezo scanner (maximum XYZ scan range of $150 \mu \mathrm{m} \times 150 \mu \mathrm{m} \times 12 \mu \mathrm{m}$ ). The tip is attached on one end of a cantilever which is "built in" at the other end. This technique can generate information such as topography and mechanical properties at the nanometer level (Aimé et al., 1994; Simon et al., 2003). The AFM characterization of samples was performed in tapping mode in ambient conditions (air). All data presented in this paper were generated with the same cantilever (with a spring constant nominally of about $0.58 \mathrm{~N} /$ m) and a scan rate at $0.5 \mathrm{~Hz}$.

For each experiment achieved in this mode, four images were recorded at the same time: trace and retrace height images (2-D/ 3-D topography images of surfaces), trace amplitude image (signal error) and phase image (mechanical properties). Only the trace flattened height image is shown in this paper for more clarity.

In this work, AFM is used, firstly, to provide information about surfaces functionalized by PEM of "classic" Love wave sensor (quartz $+\mathrm{SiO}_{2}$ guiding layer) and of "optimized" Love wave sensor (with an additional mesoporous $\mathrm{TiO}_{2}$ film). And secondly, AFM is used to study the lifetime of the E. coli-based biosensor by following the bacteria evolution over four weeks. We were particularly interested in the evolution of bacteria density on the biosensor surface, of bacteria morphology (size, shape, etc.) and of bacteria mechanical properties. Indeed, the bacteria response to the AFM tip can provide access to information such as its elasticity which can be correlated to the bacteria state (living, dying, etc.).

For this purpose, in parallel with the Love wave sensor study, another biosensor is prepared for AFM characterization of bacterial immobilization and sensor lifetime on the mesoporous $\mathrm{TiO}_{2}-\mathrm{PEM}$ film. E. coli solution was dropped on the sensor surface, the device was then stored over $24 \mathrm{~h}$, rinsed and characterized by AFM. The same areas on the surface were then monitored every 7 days. Meanwhile, stored in Milli Q water at $4{ }^{\circ} \mathrm{C}$ in a petri dish well covered. Before each test a washing step with Milli $\mathrm{Q}$ water was done.

\section{Results and analysis}

Results are divided in two parts. The first one presents the realtime acoustic responses of the biosensor during surface biofunctionalization (PEM deposition, bacteria immobilization (see Section 3.1 ), and the detection of several concentrations of cadmium (see Section 3.2). The second part presents results from AFM characterization: comparison of polyelectrolyte multilayers on $\mathrm{SiO}_{2}$ and $\mathrm{TiO}_{2}$ coated surfaces (see Section 3.3), then evolution of the bacterial sensitive film related to the sensor lifetime (see Section 3.4).

\subsection{Acoustic response for polyelectrolyte multilayer and bacteria deposition}

The experimental results with the first device (quartz $\left.+\mathrm{SiO}_{2}\right)$ were reported elsewhere (Gammoudi et al., 2010) and showed a good reproducibility. These results and those obtained with the mesoporous titania coated Love wave device are shown and compared in Fig. 2.

The real-time frequency shifts $(F-F(t=0))$ due to the PAH and PSS layers on both surfaces, and to the bacteria immobilization, are presented in Fig. 2A and B, respectively.

A higher response has been systematically observed for $\mathrm{PEM}_{1}$ when using the mesoporous titania layer $(-9.7 \mathrm{kHz})$, compared to the classical Love wave structure $(-3.4 \mathrm{kHz})$, whereas the cumulative frequency shift after the complete PEM remained similar (Fig. 2B). This could be attributed to the electrical charge of $\mathrm{TiO}_{2}$, opposite to that of $\mathrm{PAH}$. Moreover, the load of $\mathrm{TiO}_{2}$ strongly influences the passage of ions across the mesoporosity at the surface, since this space is included through the electric double layer at liquid-solid interface (Dai et al., 2012). This allows the preferential permeation of $\mathrm{PAH}$, positively charged, porous titania allowing good attachment.

The influence on bacteria immobilization is also more important in the case of the titania modified sensor, showing a frequency decrease approximately equal to $18 \mathrm{kHz}$ compared to that observed with bare silica device $(6 \mathrm{kHz})$, as it can be seen in Fig. 2B. A good reproducibility of the so-obtained steady-state frequency shifts, can be verified on the left part of Fig. 2D. This can be in agreement with a better PEM bonding on the surface, perhaps more rigid for enhanced interaction with the elastic wave, perhaps denser and presenting a greater surface electric charge, for stronger attraction of the bacteria outer cell. Indeed, the adhesion of E. coli is mainly ascribed to nonspecific Van der Waals and electrostatic attraction between positive charges of PAH and negatively charged surface of these bacteria.

\subsection{Acoustic response for cadmium detection}

A typical real-time response of a titania-modified device to increasing cadmium concentrations, from $10^{-12} \mathrm{M}$ to $10^{-3} \mathrm{M}$, is reported in Fig. 2C, while Fig. 2D illustrates the steady state frequency shifts for both devices. A few minutes after the introduction onto bacterial cell-based biosensors, low concentrations of cadmium caused an increasing frequency effect, as it can be seen in Fig. 2C. Again, the frequency shift due to the presence of cadmium in solution is larger when using the mesoporous layer. Positive frequency shifts are observed for concentrations up to $10^{-3} \mathrm{M}$, while negative frequency shifts occur from such high concentration. A similar effect is observed on the bare silica device, but the transition occurs above $10^{-1} \mathrm{M}$. 

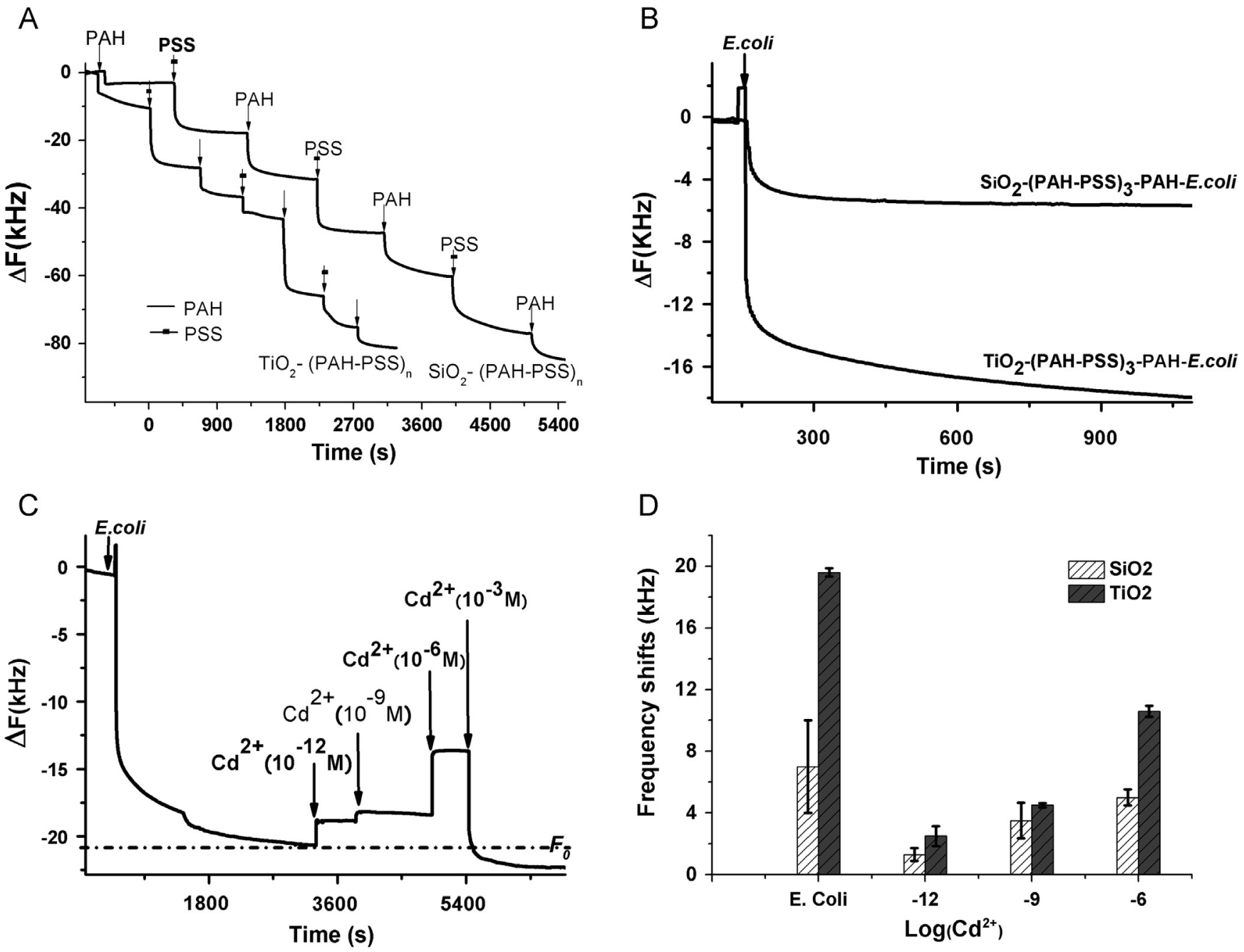

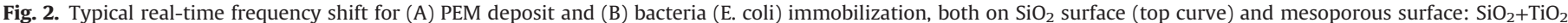

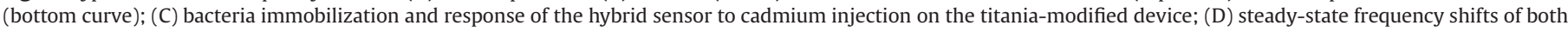
sensors (mean values and error bars were calculated from three experiments with different delay-lines).

These results have been attributed to changes in viscoelastic properties, related to modifications in bacterial metabolism. In fact, at low concentrations, heavy metals tend to replace the nutrients such as calcium, magnesium, zinc, manganese and copper, weakening or eliminating any enzyme activity resulting from these minerals.

At a high dose, there is an alteration of the structure of nucleic acids: the binding of metal cations on the phosphate of nucleic acids can cause differences in structure preventing the transcription or translation of genes. Also, reactive oxygen species (ROS), involved in respiratory cellular processes (Santos et al., 2012), can interact with metals and form free radicals, thus damaging the various cell constituents. Consequently, bacteria empty their content on the surface which involves the diminution of adsorbed mass.

\subsection{AFM results for polyelectrolytes multilayers (PEM) deposition}

In order to investigate the mechanisms of structural evolution of $\mathrm{TiO}_{2} / \mathrm{PEM}$ during assembly, the surface morphologies of the nanostructured thin films on silica and mesoporous titania were analyzed with AFM in tapping mode after each step.

Representative results can be observed in Fig. 3 with a clear difference of the PEM surface on $\mathrm{SiO}_{2}$ (Fig. 3A, C, and E) and on $\mathrm{TiO}_{2}$ (Fig. 3B, D, and F), suggesting differences in the covering process.
In particular, these results show the appearance of small granilures as circles on the first bilayer $\mathrm{PEM}_{1}-\mathrm{PAH}$, Fig 3D), in agreement with a formation from a first layer $\left(\mathrm{PAH}_{1}\right)$ inside the pores of $\mathrm{TiO}_{2}$ (Fig 3F).

\subsection{AFM results for monitoring of biofilm and biosensor lifetime}

The surface morphology of the bacterial film and of its structural evolution, on $\mathrm{SiO}_{2}$ or with additive $\mathrm{TiO}_{2}$, were also investigated by AFM. Figs. 4-6 include the various results found.

We investigated the shapes, surface morphology and size distribution of bacteria which allowed us to determine the evolution of bacteria volume and surface over time. To ensure that bacteria heights are not underestimated, the intermittent contact mode was used with a low force applied on the samples to prevent tip artifact.

Fig. 4A shows the results obtained by AFM on E. coli-based biosensor with a mesoporous $\mathrm{TiO}_{2}$ layer after 7 days old, with storage at $4{ }^{\circ} \mathrm{C}$ in MilliQ water. The real topographical information was deduced from the height image. The fine detail of the bacteria surface is highly visible with the Error signal images.

E. coli cell adhesion on the $\mathrm{TiO}_{2}$-PEM surface is mediated by interactions based especially on attractive electrostatic forces between positively charged polymer chains (PAH) and negatively charged cytoplasmic membrane of bacteria. The adhesion strength 


\section{Height images}
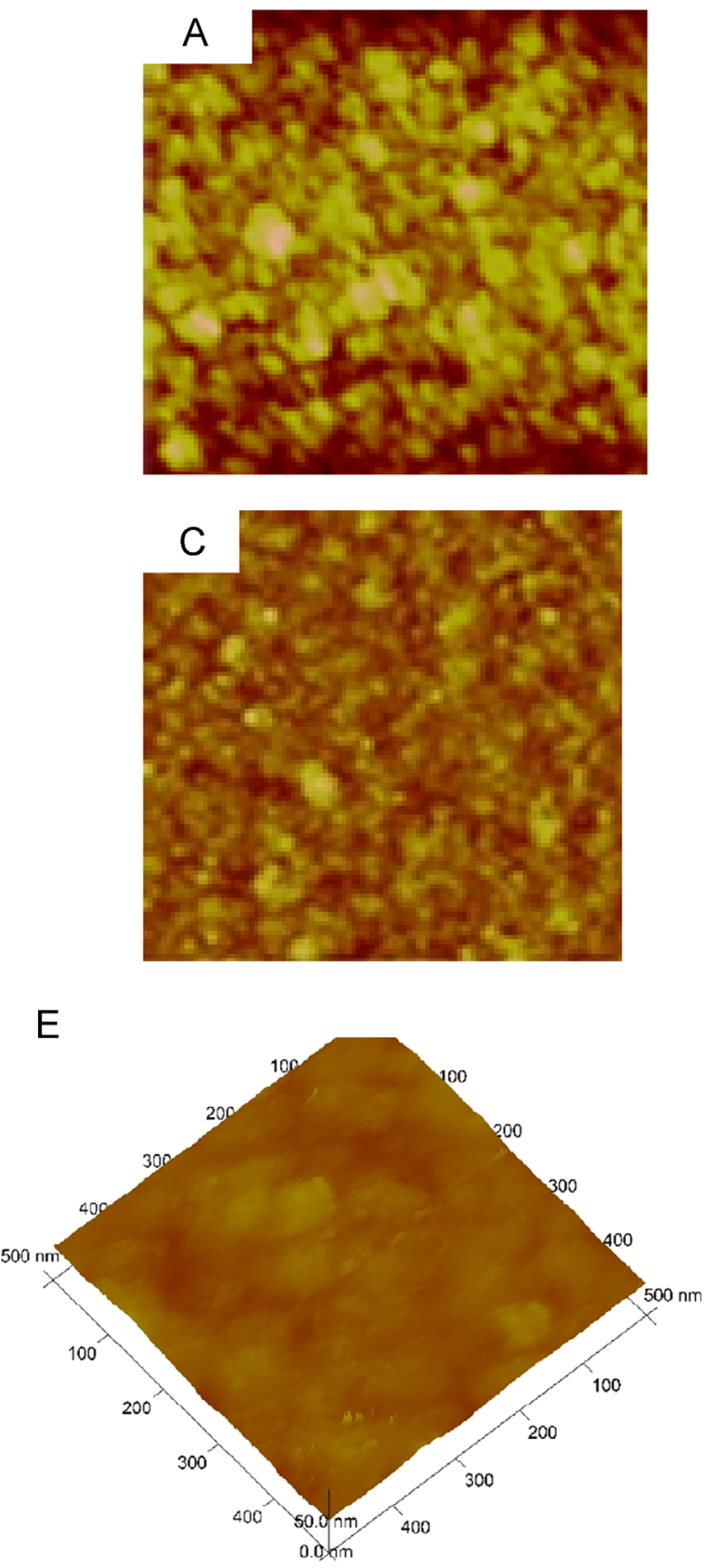
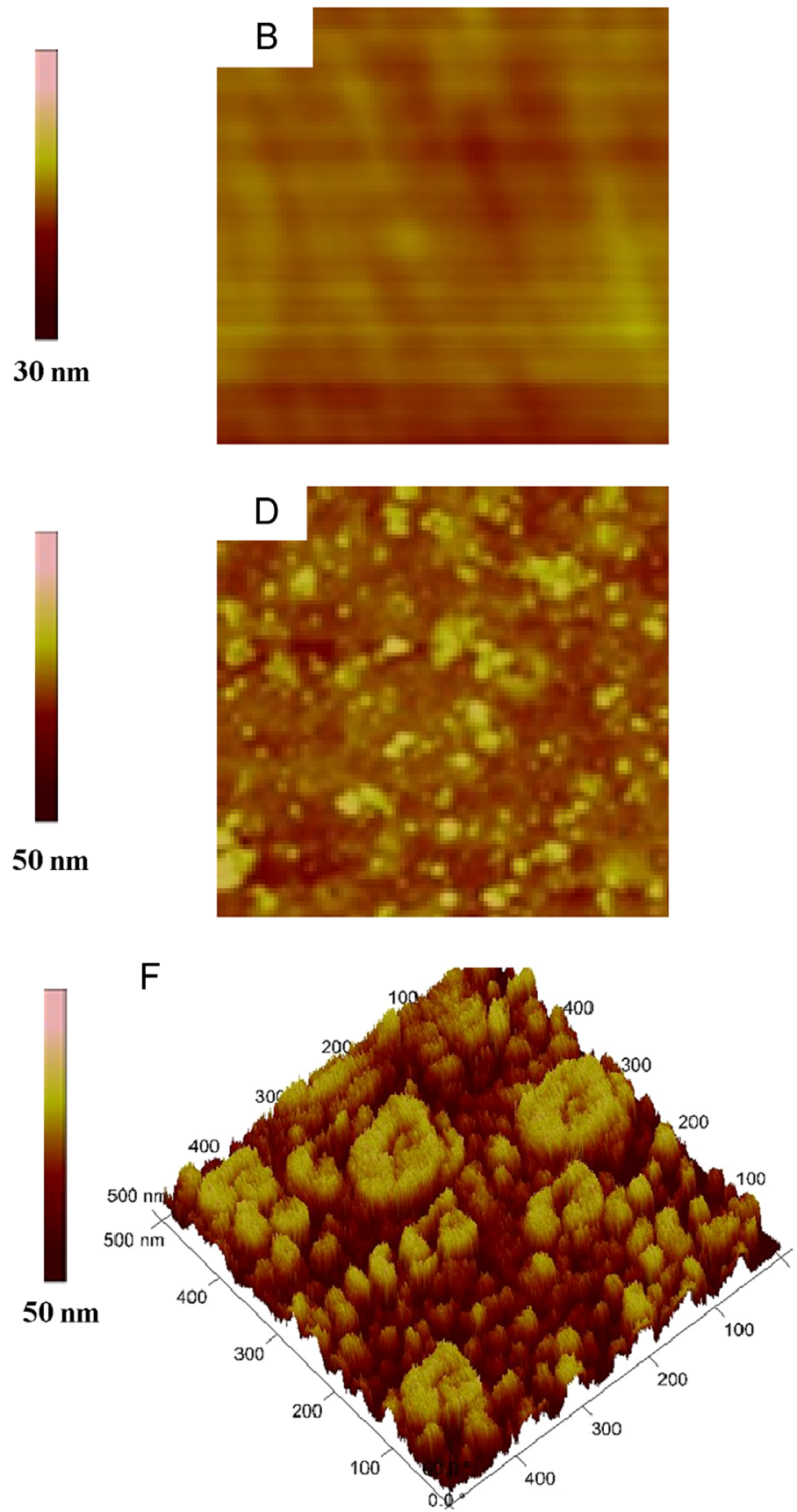

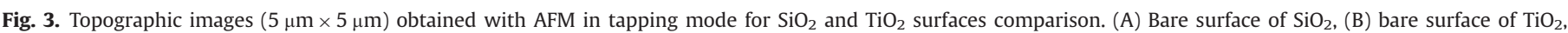

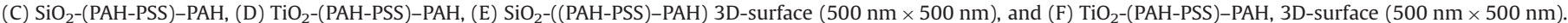

could be proportional to the homogeneity of the external layer of the film (made of PAH) and the high attachment of this layer thanks to the initial mesoporous layer. Other interactions can be involved such as hydrogen bonds and Van der Waals interactions. Indeed, AFM images obtained with the $\mathrm{TiO}_{2}$ sensor show spread and densely coated bacteria which were predominantly rods-like with the co-existence of two forms in the same sample: small bacteria (more spherical) and large bacteria (more elliptical), as shown in Fig. 4A-C. Dimension of a typical elliptical bacteria was about $1.4 \mu \mathrm{m}$ long, $0.6 \mu \mathrm{m}$ wide and $340 \mathrm{~nm}$ height, and for a spherical one, about $1 \mu \mathrm{m}$ long, $0.8 \mu \mathrm{m}$ wide and $400 \mathrm{~nm}$ height. Moreover, and as shown in Fig. 4A, some cells seem to be connected from end to end or side to side and there is no privileged orientation of bacteria.
Furthermore, the amplitude image (error signal) can provide additional information on the bacteria morphology, compared to the topographical image (height image) due to the importance of $z$ scale. Thereby, it can be inferred from Fig. 4B and C, that cells have a smooth surface with no apparent ultrastructural features. On the other hand, on the sensor surface with $\mathrm{SiO}_{2}$ (classical sensor, Fig. 4C-E), the morphologies of bacteria appear different. In particular, in Fig. 4E, they seem flattened compared to above images.

The study of the sensor lifetime was carried out over 4 weeks with a first experiment the first day after bacteria deposition (D1 = day 1), then at days 7 (D7), 15 (D15) and the last the 29th day (D29), with storage at $4{ }^{\circ} \mathrm{C}$ in Milli Q water between steps of characterization. 


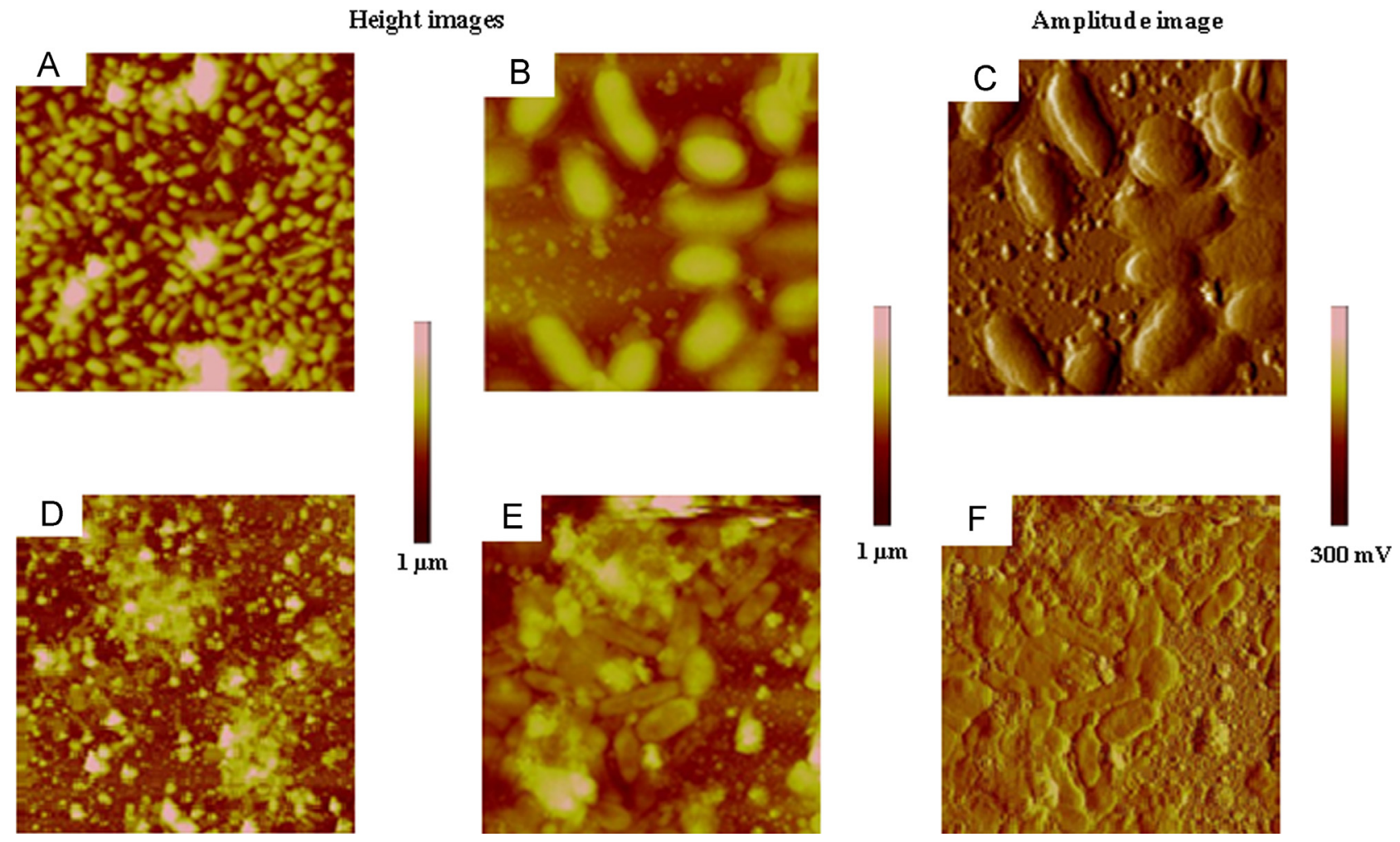

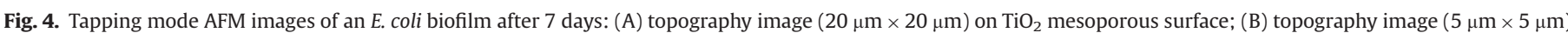

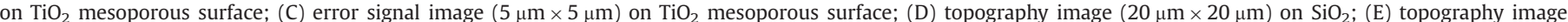
$(5 \mu \mathrm{m} \times 5 \mu \mathrm{m})$ on $\mathrm{SiO}_{2}$; (F) error signal image $(5 \mu \mathrm{m} \times 5 \mu \mathrm{m})$ on $\mathrm{SiO}_{2}$.

Based on typical results shown in Fig. 5 and from a qualitative point of view, we can make first observations. Initially, after the first day, bacteria do not cover the entire surface of the sensor and are mostly in rather spherical shape (according to statistical study performed on images with larger scans, results not shown). Seven days later, it can be seen that the integrity of bacteria cell structure is still preserved and the covering density of the sensor surface by bacteria evolve slightly. But, more important is that we begin to observe change in cell shape and size. Measurements at day 15 confirmed these observations, we note an increase in the area occupied by bacteria of the order of $60 \%$ compared to day 7 (compared to $100 \%$ at 1 st day: $53 \%$ at 7 thday; $86 \%$ at 15 th day and $48 \%$ at 29th day; Fig. 5). Despite conditions of storage unfavorable for bacteria multiplication, the dense film and even the growth of bacteria at D15 leads us to assume a source of nutrients, and hypothesis is that bacteria could continue to synthesize their proteins from nitrogenous substances, which may results from a simple reaction with the layer of $\mathrm{PAH}\left(-\mathrm{NH}_{3}^{+}\right)$. In any case, until 15th day, bacteria maintained a hydrated appearance with no evidence of collapse of the cell wall. However, at 29th day, images are dramatically different: two different cell morphologies were recognizable and could be attributed either to sick (or lysed) or to resistant cells. Indeed, much of the bacterial population present on the sensor with $\mathrm{TiO}_{2}$ has either a flattened shape with raised edges or a swollen center with collapsed edges. By analyzing broad areas of the surface sample there are still some cells which seem more resistant having the initial morphology (quasi-spherical shape).

These results are confirmed by the use of recorded AFM images from which we have deduced the average bacteria volume. Images were taken and bacteria were sized with two software images (Gwiddion, Nanoscope analysis) and also using volume formula calculations after measuring cell dimensions (Posch et al., 1997; Hollibaugh et al., 1980). For each sample, bacteria density was evaluated from surfaces of about $20 \mu \mathrm{m} \times 20 \mu \mathrm{m}$ and bacteria volume was estimated for five cells selected on images of $5 \mu \mathrm{m} \times 5 \mu \mathrm{m}$. Cell dimensions were evaluated after applying to each image a threshold function and a sharpen filter to identify the edge of the cell (it is also relevant to the required resolution and methodology for counting and sizing bacteria). As shown in Fig. 6, we observe a decrease in volume over time and identify two types of bacteria population on 29th day.

We assume that these differences (15th day and 29th day) may be due to dehydratation effects implying changes in the cell ridigity. This can be explained as well. As known, the biofilm formation takes place in four steps (van Loosdrecht et al., 1990). Firstly, access to the surface depends on the mode that allows a bacterial cell to reach the surface. This mode of transport may be by diffusion (Brownian motion or sedimentation), in the latter case the chemotaxis also plays a role. A first adhesion process then occurs, essentially physicochemical, which may be reversible. Attachment is done through cellular appendages (fibrils, polymers, etc.) which form strong bonds between the cell and the surface that can be irreversible. Finally, colonization of the surface creates the biofilm. After once, the biofilm was stored in a medium without nutrient. Bacteria manages its secretion of enzymes depending on the medium, a lack of nutrients stops the function of growth and proteins synthesis which prevents degradation such as peroxidase dismutase. This is what must have happened to the samples at the end of the month. Further experiments should be imagined to check this assumption in future works. However, that is, for now, one of the assumptions that we will check with further study.

\section{Conclusion}

Mesoporous $\mathrm{TiO}_{2}$ thin films $(100 \mathrm{~nm})$ have been employed successfully in bacteria-based biosensors to detect the presence 

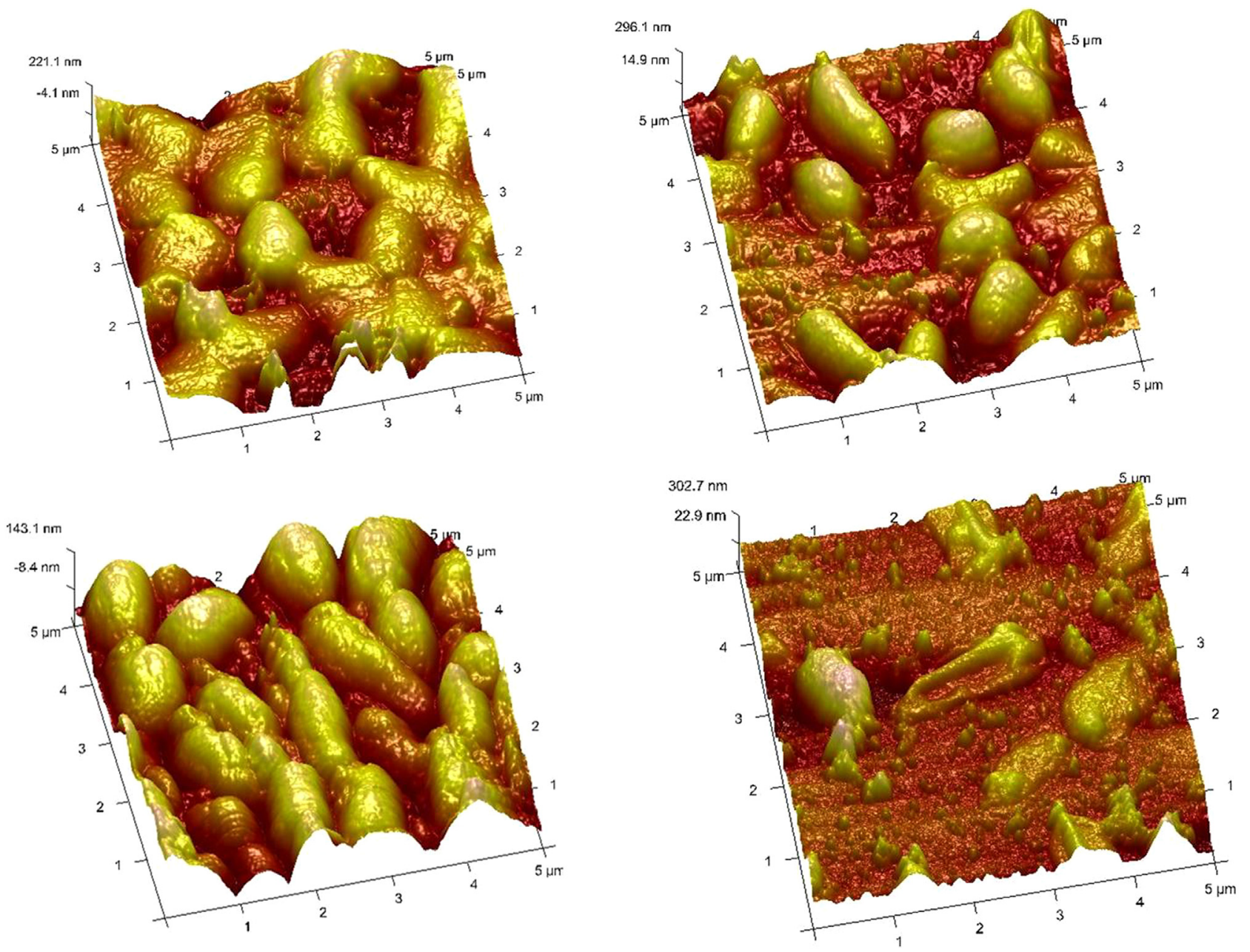

Fig. 5. AFM images (3D; $5 \mu \mathrm{m} \times 5 \mu \mathrm{m}$ ) of bacteria (E. coli) biofilm on $\left[\mathrm{SiO}_{2}(4 \mu \mathrm{m})+\mathrm{TiO}_{2}(100 \mathrm{~nm})\right]$ surface at first, 7 th, 15 th and 29 th days of life of the biosensor (storage at $4{ }^{\circ} \mathrm{C}$ in Milli Q water).

A

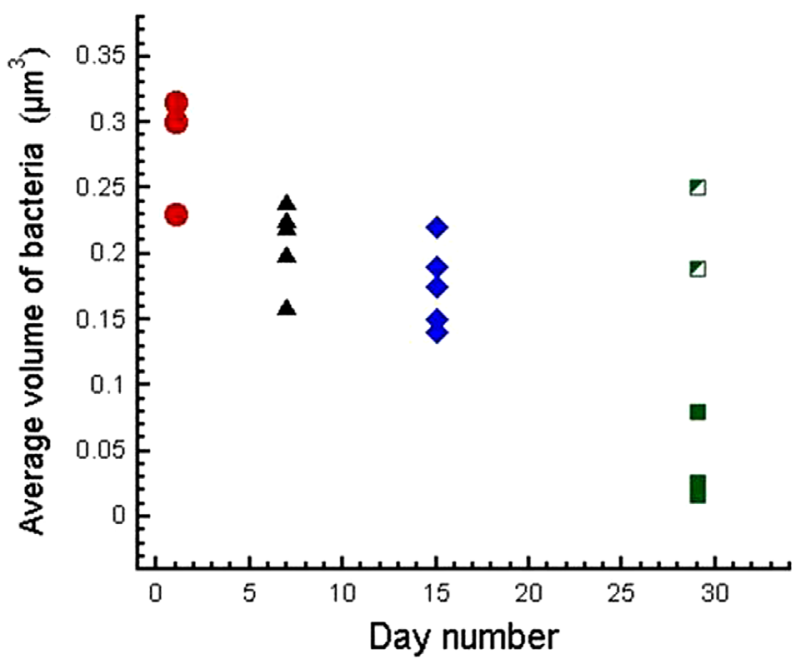

B

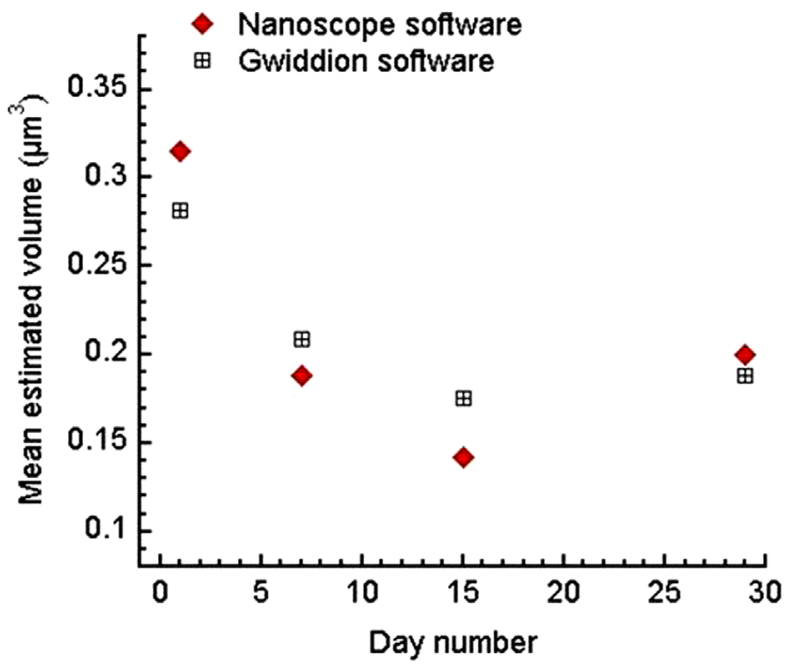

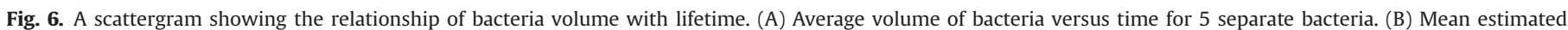

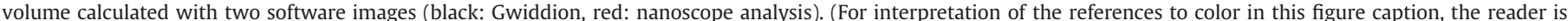
referred to the web version of this article.)

of heavy metals in aqueous solutions. Used as an overlayer on top of the $\mathrm{SiO}_{2}$ guiding layer of a Love wave sensor, it was shown that the sensitivity was improved. We assumed that this may be due to the porosity and the pore size of the titania layer, resulting in a more efficient grafting of the biosensing film (polyelectrolyte multilayer and bacteria). Further investigations with different porosities and pore sizes might support this hypothesis. 
Furthermore, AFM results were used to determine the stability of the bacterial membrane. A lifetime of several weeks was observed, demonstrating the good stability of the so modified sensor.

This biosensor is not specific for a single metal, but it provides a highly global response of the heavy metals presence in trace. Such rapid response of measurements could be applied with other micro-organisms for achieving toxicity tests such as algae.

Our near objective is the miniaturization of the system making microfluidic tests for in situ detection.

\section{Acknowledgments}

The overall project on the bacterial-based Love wave device for heavy metals detection was conducted through the CMCU Project no 10G1103. PDMS chips were designed in the frame of Ph.D. works of $\mathrm{H}$. Tarbague, through the ANR project BIOALERT. The authors also want to thank M. Benoît from LAAS-CNRS (Toulouse France) for processing of piezoelectric delay-lines through the National Technical Realization Network RTB. Bacteria were provided by the Centre d'Etudes du Bouchet (DGA, France).

\section{References}

Aimé, J.P., Elkaakour, Z., Odin, C., Bouhacina, T., Michel, D., Curély, J., Dautant, A., 1994. J. Appl. Phys. 76, 754-762.

Bagher, H., Afkhami, A., Saber-Tehrani, M., Khoshsafar, H., 2012. Talanta 97, 87-95.

Bass, J.D., Grosso, D., Boissière, C., Belamie, E., Coradin, T., Sanchez, C., 2007. Chem. Mater. 19, 4349-4356.

Boissière, C., Grosso, D. Lepoutre, S., Nicole, L., Brunet Bruneau, A., Sanchez, C. 2005. Langmuir 21, 12362-12371.

Bouhacina, T., Desbat, B., Aimé, J.P., 2000. Tribol. Lett. 9, 111-117.

Castillo, J., Gaspar, S., Leth, S., Niculescu, M., Mortari, A., Bontidean, I., Soukharev, V., Dorneanu, S.A., Ryabov, A.D., Csoregi, E., 2004. Sens. Actuators B: Chem. 102, 179-194.

Dai, G., Zhao, Li., Wang, S., Hu, J., Dong, B., Lu, H., Li, Jing, 2012. J. Alloys Compd. 539, 264-270.

Fertier, L., Cretin, M., Rolland, M., Durand, J-O., Raehm, L., Desmet, R., Melnyk, O., Zimmermann, C., Dejous, C., Rebière, D., 2009. Sens. Actuators B: Chem. 140, 616-622.
Gammoudi, I., Tarbague, H., Othmane, A., Moynet, D., Rebière, D., Kalfat, R., Dejous, C., 2010. Biosens. Bioelectron. 26, 1723-1726.

Gauthier, S., Aimé, J.P., Bouhacina, T., Desbat, B., Attias, A.J., 1996. Langmuir 12 4840-4849.

Guven, K., Togrul, S., Uyar, F., Ozant, S., De Pomerai, D.I., 2003. Enzyme Microb. Technol. 32, 658-664.

Hepel, M., Blake, D., McCabe, M., Stobiecka, M., Coopersmith, K., 2012, in: American Chemical Society Symposium Series, vol. 1112, pp. 207-240 (Chapter 8).

Hollibaugh, J.T., Fuhrman, J.A., Azam, F., 1980. LimrtoL Oceanogr 25, 172-181.

Matés, J.M., Segura, J.A., Alonso, F.J., Márquez, J., 2010. Free Radical Biol. Med. 49, 1328-1341.

Nicole, L., Boissière, C., Grosso, D., Quach, A., Sanchez, C., 2005. J. Mater. Chem. 15, 3598-3627.

Panphlett, R., McQuilty, R., Zarkos, K., 2001. Neurotoxicology 22, 401-410.

Posch, T., Pernthaler, J., Alfreider, A., Psenner, R., 1997. Appl. Environ. Microbiol. 63, $867-873$.

Sanchez, C., Boissière, C., Coupé, A., Goettmann, F., Grosso, D., Julián, B., Llusar, M., Nicole, L., 2005. Stud. Surf. Sci. Catal. 156, 19-36.

Santos, A.L., Gomes, N.C.M., Henriques, I., Almeida, A., Correia, A., Cunha, Â., 2012. J Photochem. Photobiol. B: Biol. 117, 40-46.

Schonhoff, M., Opin, C., 2003. Colloid Interface Sci. 8, 86-95.

Seigneur, C., Vijayaraghavan, K., Lohman, K., Karamchandani, P., Scott, C., 2004. Environ. Sci. Technol. 38, 555-569.

Sereshti., H., Khojeh., V., Samadi. S., 2011. Talanta 83, 885-890.

Simon, A., Cohen-Bouhacina, T., Porte, M.C., Aime, J.P., Amédée, J., Bareille, R. Baquey, C., 2003. Cytometry A 54, 36-47.

Simon, A., Cohen-Bouhacina, T., Porte, M.C., Aime, J.P., Amédée, J., Bareille, R. Baquey, C., 2004. Cell. Mol. Biol. 50, 255-266.

Stobiecka, M., Molinero, AA., Chałupa, A., Hepel, M., 2012. Anal. Chem. 11, 4970-4978.

Tarbague, H., Lachaud, J.-L., Destor, S., Vellutini, L., Pillot, J.-P., Bennetau, B., Pascal, E., Moynet, D., Mossalayi, D., Rebière, D., Dejous, C., 2010. J. Integrated Circ. Syst. 2, 125-133.

Tiemann, M., 2007. Chem. Eur. J. 13, 8376-8388.

Tortissier, G., Blanc, L., Tetelin, A., Zimmermann, C., Lachaud, J.-L., Boissière, C., Sanchez, C., Dejous, C., Rebière, D., 2009. Sens. Lett. 7, 984-988.

Valderi, L.D., Dirce, P., Adilson, J.C., 1998. Spectrochim. Acta B: At. Spectrosc. 53, 1527-1539.

van Loosdrecht, M.C.M., Zehnder, A.J.B., 1990. Cellular \& Molecular Life Sciences 46, 817-822.

Wang, X., Cui, F., Lin, J., Ding, B., Yu, J., Al-Deyab, S.S., 2012. Sens. Actuators B: Chem. $171,658-665$.

Wood, J.M., Wang, H.K., 1983. Environ. Sci. Technol. 17, 582-590.

Zhou, S., Wei, C., Liao, C., Wu, H., 2008. J. Environ. Sci. 20, 1514-1518.

Zimmermann, C., Rebière, D., Dejous, C., Pistré, J., Chastaing, E., Planade, R., 2001 Sens. Actuators B 76, 86-94. 